\title{
Geleneksel ve Sosyal Medyada Reklama Yönelik Tutum ve Reklam Değeri Arasındaki Ilișkinin Karșılaștııılması
}

\author{
G. Motif ATAR ${ }^{12}$ \\ N. Bilge ISPIR ${ }^{3}$
}

\begin{abstract}
öz
İnternet kullanan kişilerin sayısının artmasına bağlı olarak sosyal medya, tüketiciler ile iletişim biçimini değiştiren bir platforma dönüşmüştür. Bu hız ve etkileşimlilik sosyal medyanın giderek büyüyen bir reklam ortamı olmasını sağlamış ve geleneksel medya ile arasındaki fark açılmıştır. Geleneksel bir mecra olarak televizyonun günümüzde yaygın olarak kullanılmasına rağmen, sosyal medya reklamları, televizyon reklamlarının etki alanını daraltmaya başlamıştır. Dolayısıyla bu iki farklı mecradaki reklamlara yönelik tüketici tutumları da farklılaşmaktadır. Bu çalışma, geleneksel medyada televizyon ve sosyal medyada Facebook ve Instagram'daki reklamlara yönelik, tüketici tutumu ile algılanan reklam değeri arasındaki ilişkiyi açıklamaya çalışmaktadır. İncelenen mecralarda reklama yönelik tutumu ve algılanan reklam değerini ölçmek için Ducoffe (1995) tarafından geliştirilen ölçek uyarlanmış ve her üç mecra için reklama yönelik tutum ve algılanan reklam değeri ayrı ayrı ölçülmüştür. Elde edilen sonuçlara göre sosyal medya reklamları geleneksele göre daha bilgilendirici, eğlendirici bulunmakta ve reklam değeri daha yüksek algılanmaktadır.
\end{abstract}

Anahtar Kelimeler: Reklam değeri, tutum, sosyal medya, geleneksel medya

Atıf: Atar, G. M. ve İspir, N. B. (2019). Geleneksel ve Sosyal Medyada Reklama Yönelik Tutum ve Reklam Değeri Arasındaki İlișkinin Karșılaștırılması. Akdeniz Üniversitesi Iletișim Fakültesi Dergisi, Haziran (31), s. $305-322$

1 Sorumlu Yazar / Corresponding Author

2 Dr. Öğretim Üyesi, Anadolu Üniversitesi İletişim Bilimleri Fakültesi, gmatar@anadolu.edu.tr, ORCID Numarası: 0000-0003-2074-3568.

3 Doç. Dr., Anadolu Üniversitesi İletişim Bilimleri Fakültesi, nbispir@anadolu.edu.tr, ORCID Numarası: 00000001-7572-9048. 


\title{
A Comparison of Relationship Between Attitude Toward Advertising And Advertising Value In Traditional And Social Media
}

\begin{abstract}
With the increase in number of individuals using the Internet, social media has turned into a platform that changes form of communication with consumers. The speed and interactivity have led social media to become an ever-increasing advertising platform, and the difference between social and traditional media has widened. Although as a traditional medium, television is still widely used today, social media advertising has led the scope of television advertising to be narrowed. Consequently, consumers' attitudes toward advertising on these two different media have diverged as well. This study focuses on explaining the relationship between consumer's attitude and perceived advertising value for advertisements on television in traditional media and in social media, specifically Facebook and Instagram. In the media studied, the model developed by Ducoffe (1995) has been adapted to measure attitude toward advertising and perceived advertising value, and these have been measured separately for each of the three media. According to the results obtained, social media advertising is regarded more informative and entertaining than traditional media advertising, and its advertising value is perceived much higher.
\end{abstract}

Keywords: Advertising value, attitude, social media, traditional media

\section{Giriș}

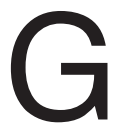
ünümüzde sosyal medya kullanan kişilerin sayısının gün geçtikçe artmasıyla birlikte sosyal medya aracılığıyla iletilen mesajlarda da artış gözlemlenmektedir. Böylece işletmeler markalarını geniş kitlelere duyurma fırsatı bulmaktadırlar. Sosyal medya bilgi edinme, fikir alışverişi, farkındalık, satın alma davranışı, yorum ve değerlendirme gibi tüketici davranışlarını da etkilemektedir. Bu değişim ve dönüşümler tüketicilerin isteklerini, beklentilerini ve alışkanlıklarını da değiştirmeye başlamıştır. Sosyal medyanın sağladığı avantajlar nedeniyle dijital medyaya yapılan reklam yatırımları da artmakta ve işletmeler ulaşmak istedikleri tüketicileri hedefleyerek yatırımlarını bu doğrultuda yapmaktadır. Geleneksel medya etkisini sürdürürken, dijital medya insanların hayatlarını şekillendiren bir mecra haline gelmiştir ve pazarlama dünyasının ilgi odağındadır. Dijital medya ürün önerileri ve benzeri pazarlama girişimlerine yönelik yeni tüketici tepkisi ölçütleri yaratan fırsatlar sunmaktadır. Böylelikle bilgi akışının kontrolü pazarlamacıdan tüketiciye doğru yön değiştirmiştir. Bu da tüketiciye daha fazla bilgiye tepki verme seçeneği sunmaktadır.

Bilgisayarlar, cep telefonları ve benzeri cihazların hızı, kapasitesi ve güvenilirliği, tüketicilerin hayatlarını düzenlemesinde, insanlarla iletişim kurmasında ve bilgiye erişmesinde onları daha değerli hale getirmektir. Giderek artan donanım performansı 
aynı zamanda bu cihazların reklam mesajlarını ilgili tüketicilere ulaştırmada daha sağlam platformlar haline geleceği anlamına gelmektedir; çünkü reklam mesajlarını tüketiciye ulaştırmak için daha ilgi uyandıran yaratıcı düzenlemeleri ve daha karmaşık ve cazip uygulamaları desteklemektir (Kim, 2008). Sosyal medya sağladığı bu olanakların yanı sıra rekabeti giderek arttırmıştır. Bu yüzden akılı stratejiler geliştirerek tüketicilere ulaşmak önem taşımaktadır. Tüketicilerin reklama olan ilgisi reklam değeri ile ilgili algısını etkilemektedir. Her gün onlarca reklama maruz kalan tüketicilerin, bu reklamları nasıl değerlendirdiği algılanan reklam değeri açısından önemlidir.

Ducoffe (1995), reklamı değerli yapan şeyi anlamak amacıyla, tüketicilerin reklamdan çıkardığı temel yarar ve zararları tanımlamıştır ve bu unsurlar tüketicilerin reklam değerini nasıl değerlendirdiğini açıklamaktadır. Bu çalışma, geleneksel mecrada televizyon; sosyal medyada Facebook ve Instagram reklamlarına yönelik tutumu ve algılanan reklam değerini ölçmeyi amaçlamaktadır.

\section{Reklam Ortamı Olarak Televizyon}

Televizyonun hem bir kitle iletişim aracı hem de bireylerin üzerinde sahip olduğu etki gücü, bir reklam ortamı olarak kullanılmasını sağlamıştır. İlk kez 1940’lı yıllarda bir reklam aracı olarak kullanılmaya başlayan televizyon, ses ve görüntüyü aynı anda iletebilmesini sağlayan teknik özellikleri ve milyonlarca kişiyi kendine bağlayan içeriksel nitelikleriyle reklamcılar açısından oldukça cazip bir ortam olarak görülmüştür (Elden, 2013).

Televizyonun, sesi ve görüntüyü aynı anda çok kişiye iletebilmesi en büyük avantajıdır. Sahip olduğu teknik üstünlükler sayesinde reklam mesajlarını etkili bir şekilde hedef kitlelere aktarabilmekte, her yaştan, eğitimden ve gelir grubundan kişilere ulaşabilmektedir. Ancak televizyon, pahalı bir reklam ortamıdır ve televizyon kanallarında yayınlanma maliyeti yüksektir (Elden, 2013). Illetişim teknolojilerinin zaman içindeki gelişim ve değişimlerine rağmen televizyon, geleneksel bir mecra olarak popülerliğini korumaktadır. Ancak internetin hızı ve sunduğu seçenekler bir reklam ortamı olarak televizyonu olumsuz etkilemektedir. İnternette reklamsız bir içeriğe ulaşmak ya da reklamı atlamak mümkünken, tüketici televizyonda dakikalar süren reklam aralarında zapping yaparak reklamları izlemeyi reddetmektedir. Ya da zapping yapmasa bile televizyonda yayınlanan reklamları bilinçli olarak seyrettiği ölçülememektedir. İzleyiciler kimi zaman televizyonda yayınlanan bir diziyi ya da filmi daha sonra reklamsız olarak sanal ortamda izlemeyi tercih etmektedir. Süher ve İspir'in çalışması da (2010) göstermektedir ki reklamdan kaçınma en çok televizyonda ortaya çıkmaktadır ve teknolojik gelişmeler de televizyonda reklamdan kaçınmayı daha kolay hale getirmektedir.

\section{Sosyal Ağ Siteleri ve Reklam Ortamı Olarak İnternet}

"Sosyal medya; kullanımı e-mail ve telefon kadar doğal hale gelmiş olan ve kurumların 
genç tüketicilere kolay, elverişli ve şeffaf bir yolla ulaşmasını mümkün kılan bir iletişim kanalıdır" (Duffett, 2018, s. 2). Sosyal ağ siteleri, kişilerin sınırlı bir sistem içinde herkese açık veya yarı-açık bir profil inşa etmelerine, ortak bağ kurdukları bir başka kullanıcılar listesiyle iletişim kurabilmelerine ve sistem içinde kendilerinin ve başkalarının bağlantı listelerine bakabilmelerine ve etkileşim kurabilmelerine izin veren web-tabanlı hizmetler olarak tanımlanabilir. Bu bağlantıların yapısı ve terminolojisi, siteden siteye farklılık gösterebilmektedir (Boyd ve Ellison, 2008). Sosyal ağ siteleri, kullanıcıların kişisel bilgi içeren profiller yaratarak, arkadaşlarını ve meslektaşlarını bu profillere erişmeye davet ederek ve birbirlerine e-mailler ve anlık mesajlar göndererek iletişim kurmasına olanak sağlayan uygulamalardır. Bu kişisel profiller fotoğraf, video, ses dosyaları ve bloglar dahil olmak üzere her türlü bilgiyi içerebilir (Kaplan ve Haenlein, 2010).

Sosyal medyanın ilk rolü, geleneksel bütünleşik pazarlama iletişimi araçlarının kullanımıyla tutarlılık içindedir. Yani şirketler, müşterileriyle blog gibi platformlar ve Facebook ve MySpace grupları aracılığıyla iletişim kurmak için sosyal medyadan yararlanabilirler. Bu medyalar şirket tarafından ya da başka kişi veya kurumlar tarafından sponsorlu olabilir. Sosyal medyanın tanıtımla ilişkili ikinci rolü ise tüketicilerin sosyal medyayı birbirleriyle iletişim kurmak amacıyla kullanmalarıdır. Sosyal medyanın müşterilerin birbirleriyle konuşmasına imkan tanıyan bu ikinci rolü, bir anlamda, geleneksel ağızdan ağıza iletişimin bir uzantısıdır (Mangold ve Faulds, 2009). Tüketiciler bilgilerini, ürün ve hizmet deneyimlerini, şikayetlerini ve memnuniyetlerini diğer tüketicilerle paylaşmak için sosyal medyaya başvurmaktadır.

Online sosyal ağ sitelerinin (örneğin Facebook, Twitter gibi) hızla artan popülaritesi, hem pazarlamacıların hem de tüketicilerin, online marka topluluklarıyla tüketici-marka ilişkileri kurmalarını ve teşvik etmelerini sağlamıştır. Bu online marka topluluklarında, pazarlamacılar çok yönlü bir marka inşa aracı olarak online marka topluluklarını kolay hale getirebilirler ve böylece ürün ve hizmetler için ikna edici reklam mesajları yaratabilir, düzenleyebilir ve yayabilirler (Lee vd., 2011). Sosyal ağların kullanıcı sayısı gün geçtikçe artmaktadır. Facebook'un 1 milyar aktif kullanıcı sayısına, Twitter'ın 300 milyondan fazla kullanıcıya ulaşması bu mecraları reklamcılar için cazip bir alan haline getirmiştir. Sosyal ağ sitelerinde her gün daha kullanıcılar tarafından bilgi üretilmekte ve güncellenmekte, bu durum reklamcıların hedef kitleye dair daha fazla veriye ulaşmasına ve böylece kişiye özel reklamların yapılabilmesine olanak sağlamaktadır (Aslan, 2017). Tüketicilerin reklamı algılama biçimleri takip ettikleri mecra ile doğrudan ilişkilidir. Tüketicilerin reklam içeriklerine yönelik algı farklılıklarının temelinde medyaya karşı oluşturdukları tutum yatmaktadır. Bunun en önemli nedeni, medyanın, bir reklamın içeriğini sunma işlevine sahip olmasıdır (Becan, 2013). Geleneksel medyada etkileşimlilik ve tüketici tepkilerini hızı bir şekilde ölçebilme imkanı yokken, sosyal medya "beğen" butonu ile bu fırsatı yaratmakta, zaman ve mekan sınırını ortadan kaldırarak tüketici tepkilerini anlık olarak takip edebilmektedir.

Internet ve diğer teknolojilerin gelmesiyle birlikte, tüketiciler ve pazarlamacılar arasındaki etkileşim giderek daha belirgin hale gelmektedir. Tüketiciler ticari web sitelerine girip araştırma yaparak bilgi edinebilir ve toplayabilir, kendi tercihlerini 
internette yayınlayabilir ve özelleştirebilir ve diğer tüketicilerle ve ayrıca ürün ve hizmet sağlayıcılarıyla iletişim kurabilirler. Benzer şekilde pazarlamacılar da tüketicilerden elde ettikleri bilgileri reklam mesajlarını özelleştirmede, kitlelerini kategorize etmede, belli türde bilgi ve ürün için tüketici araştırmasını kolaylaştırmada ve gelecek ürün ve hizmetleri geliştirmek amacıyla tüketicilerin tercihleri hakkında bilgi toplamada kullanabilirler. Pazarlamacılar öte yandan e-mail, web siteleri, canlı operatörler ve video konferans aracılığıyla bilgi, eğlence, tüketici hizmeti ve teknik destek gibi hizmetler sunarak tüketicilere potansiyel olarak daha keyifli bir deneyim sunabilir (Pavlou ve Stewart, 2000). Özellikle marka bilinirliği, müşteri ile ilişkilerin güçlendirilmesi, kampanya ya da hizmet tanıtımları konusunda sosyal ağ reklamcılığının önemli olduğu düşünülmekle birlikte sosyal ağ reklamcılığı, özellikle sosyal ağlarda gerçekleştirilen reklamların satın alma davranışına etkisinin tam olarak ölçülemeyeceği yönündeki eleştirilerle de karşılaşmaktadır. Buna rağmen sosyal ağ reklamcılığı gelirlerinin reklam piyasasındaki payı gün geçtikçe artmaktadır (Aslan, 2017).

Reklam kampanyaları, firmanın hedefleri doğrultusunda marka farklılıkları ile ilgili farkındalık yaratmayı, bilgi vermeyi, tanıtım yapmayı amaçlar. Reklam yapmanın temelinde, tüketicileri markanın ürün veya hizmetini satın alması için etkilemek ve bunun karşılığında da şirketin satışlardan kar elde etmesi yatar. Hedef tüketicileri ve reklam araçlarının yapısını anlamadan yapılan reklam risk taşır. Etkili reklam olarak değerlendirilen reklamdan elde edilen karlar arasındaki ilişkiler, anlaşıması gereken meselelerden biridir (Ertugan, 2017). İnternet gibi yeni medyalar yoluyla interaktif reklam kullanımı, reklamla ve reklamın etkisiyle ilgili geleneksel varsayımlar ile pazardaki iletişimin gerçeklikleri arasındaki ayrıma da parmak basar. Reklam pratiği ve araştırmasına yönelik geleneksel yaklaşımlar, üstü kapalı bir şekilde, reklamın, firmanın tüketici için yaptığı bir şey olduğunu varsayar. İnteraktif reklamcılık ise bunun oldukça sınırlı bir reklamcılık görüşü olduğunu söyler ve tüketicilerin reklam için neler yaptıklarını anlamak gerektiğinin altını çizer. Tüketicilerin bilgi arama, ilgi alanına yönelik bilgiyi seçme, bilgiyi işleme ve kullanma ve bilgiye tepki verme sebepleri, reklamın etkilerini anlamak ve interaktif bir bağlamda reklam etkinliği ölçütleri tasarlamak için son derece önemlidir. Hem bilginin elde edilebileceği kaynakların hem de bu bilginin işlenme yönteminin kişi tarafından seçilmesi, tüketici davranışının giderek daha önemli hale gelen bir belirleyicisidir. Bilginin tüketici tarafından kontrolünün etkisini hesaba katmayı başaramayan pazar bilgi sistemleri, en iyi intimalle, eksik ve potansiyel olarak yanıltıcı olacaktır (Pavlou ve Stewart, 2000). Sosyal medya yoluyla reklamcılık, en ucuz ve en hedefe yönelik reklamcılık türlerinden biri olabilir. Şirketlerin, müşterilerinin artık bu mecrada ulaşılabilir olduğunu ve bunun da güncel kalabilmek için bu ortamda rahat olabilmelerini gerektirdiğini anlaması gerekir. Ancak, bu yeni reklam tekniğini keşfeden şirketlerin giderek artmasıyla birlikte, kısa yol bulmak daha zor hale gelecektir ve birçok şirket sesini duyurabilmek için mücadele etmektedir. Dolayısıyla, sosyal ağ her ne kadar pazarlama için geniş bir kapsam sağlasa da giderek artan rekabet tanınır olmayı güçleştirmektedir ancak akıllı bir strateji uygulayarak bunu başarmak mümkündür (Curran vd., 2011). Tüketicilerin tutum ve beklentilerini doğru belirleyebilmek bu açıdan önem taşımaktadır. 


\section{Geleneksel Medya ile Sosyal Medya Arasındaki Farklılıklar}

“Internet reklamcılığı modern reklamcılığın devamı ve yeniden üretimidir” (Toros, 2016, s. 24).

Geleneksel mecra ile internet ortamı karşılaştırıldığında aralarındaki en önemli fark iletişimin yönüdür. Geleneksel mecralarda mesaj, tek bir kaynaktan birçok kişiye iletmektedir. Geleneksel mecralarda birey pasif olduğundan gelen bilgiyi kontrol edememektedir. Geleneksel mecranın tersine, internet ortamında çift yönlü bir iletişimin olduğu söylenilebilir. İnternet ortamı sayesinde insanlar, bilgiyi tüketirken aynı zamanda geri bildirim yolu ile bilgi üretebilmektedirler. Etkileşim sayesinde tüketicilerin, geleneksel mecraların tersine bilgiyi kontrol etmesi daha kolaylaşmaktadır. Ayrıca geleneksel mecralar belli bir yer ve zaman sınırı içerisindedirler. İnternet, zaman ve yer sınırlılığı kavramını ortadan kaldırarak kolay ulaşılabilirlik özelliği taşımaktadır. (Becan, 2013). Evde, işte, seyahatte kısacası internetin olduğu her yerde tüketiciye her an ulaşabilmek mümkündür.

Geleneksel olarak kitle medya endüstrisinde (gazete, dergi, sinema, radyo ve televizyonda) izleyiciler tarafından tüketilmesi için içerikler tasarlanmakta ve planlanan akış içinde yayınlanmaktadır. Bu akış içerisinde reklamlar, tüketiciye en etkili iletişimin gerçekleştirileceği zamanda ve alanda yayınlanmaktadır. Bu süreçte izleyici ya da okuyucu reklamlara ya hiç müdahale edemeden ya da sınırlı tercih olanakları ile maruz kalmaktadır (Toros, 2016). Geleneksel reklamcılıktan farklı olarak internet reklamcıığının getirdiği yenilikler ve olanaklar, sadece bir tanıtım aracı olmasının yanı sıra bir satış ve dağıtım kanalı olarak kullanıımasını da beraberinde getirmiştir (Cömert ve Yükselen, 2017). Baltar ve Brunet (2011), Facebook'un veya sosyal ağ sitelerinin tepki oranının geleneksel reklamlardan veya televizyon reklamlarından çok daha yüksek olduğunu ileri sürmektedir. Televizyondaki ve sosyal medyadaki reklamlar kıyaslandığında, internet ve sosyal medyanın daha doğru, gerçekçi ve interaktif reklam kaynağı olduğuna inanıır (Dar vd., 2014).

Geleneksel reklamcılıkta kişi, bir derginin içerik uzmanlığı ve reklamı yapılan ürün tipiyle derginin ilişkisi bakımından kaynak güvenilirliğine bakabilir (örneğin Playboy dergisinde reklamı yapılan çamaşır deterjanı, muhtemelen uyumsuz bir eşleşme olarak görülecektir) (Shamdasani vd., 2001).

Tüketici kendi reklam tercihlerini yaparken, diğer taraftan her zamankinden daha fazla, hemen ve doğrudan reklamlara tepki verme, göz ardı etme ya da tamamen engelleme olanakları bulmaktadır. Aynı zamanda enformasyon arayışında olan kullanıcıların aktifliği, diğer kullanıcılarla girdikleri etkileşim ile de güçlenmektedir. Bu nedenle geleneksel mecra reklamları ile karşılaştırıldığında, etkileşimli reklamların etkisini zayıf bulanların sayısı artmaktadır, bu durumun da reklam verenler ve reklamcılar açısından erişim ve etki sorunları doğurabileceği tartışılmaktadır (Toros, 2016). 


\section{Reklama Yönelik Tutum}

Tutum, bireyin kendine ya da çevresindeki herhangi bir nesne, konu ya da olaya karşı deneyim, bilgi, duygu ve güdülerine dayanarak oluşturduğu zihinsel, duygusal ve davranışsal bir tepki ön eğilimidir (İnceoğlu, 2011). Kişilerin oluşturdukları tutumlar onların satın alma kararlarında doğrudan etkilidir. Satın alma kararı da belirli bir tutumun pekiştirilmesini ya da değiştirilmesini etkilemektedir (Odabaşı ve Barış, 2013). Lutz (1985) reklama yönelik tutumu, belirli bir olaya maruz kalma durumu süresince belirli bir reklam uyaranına olumlu ya da olumsuz tavır gösterme eğilimi olarak tanımlamaktadır (MacKenzie vd., 1986). Mehta'ya göre (2000), reklama yönelik tutum, reklamın etkililiğinin önemli bir göstergesidir çünkü tüketicinin reklama yönelik bilişsel yeteneği düşüncelerine ve duygularına yansımakta ve ardından reklama yönelik tutumunu etkilemektedir.

Çakır ve Çakır'ın yaptığı araştırmada elde edilen bulgulara göre (2007, s. 55) tüketiciler reklamı değerli, yararlı ve önemli bulduklarında, yani bilişsel değerlendirmeleri olumlu olduğunda reklama yönelik tutumları da olumlu olmaktadır. Tüketici reklamlardan rahatsızlık duysa bile, eğer reklam sayesinde bilgileniyor ya da eğleniyorsa reklamlara yönelik genel tutumu da olumlu olmaktadır. Süher ve İspir (2010) yaptıkları çalışmada reklama yönelik tutumları incelemiş ve insanların televizyondaki reklamları daha eğlenceli olarak değerlendirdiğini, gazete reklamlarını daha bilgilendirici gördüklerini ortaya koymuştur. Ayrıca SMS reklamlarına yönelik tüketici tutumlarını belirleyen en önemli değişkenin eğlendiricilik olduğunu; bunu, rahatsız edicilik, güvenilirlik ve bilgilendiriciliğin takip ettiğini bulmuşlardır (İspir ve Suher, 2009). "Reklam, tüm tutumlar üzerinde öncül etkiler olarak görülen pozitif ve negatif duygular yaratır. Ancak, tüketicilerin reklam değerini değerlendirmesinde can alıcı olduğu düşünülen şey, tepkilerin kendisi değil, tüketicilerin bu tepkilerle ilgili bilişsel değerlendirmeleridir" (Ducoffe, 1996, s. 24).

\section{Reklam Değeri}

"Değer, bazı davranış ve amaçları diğer davranış ve amaçlardan ya bireysel ya da sosyal olarak daha tercih edilebilir bulan sürekliliği olan inanışlardır" (Odabaşı ve Barış, 2013, s 158). Reklam değeri, bir reklamın bir tüketici için görece değerinin veya yararının öznel değerlendirmesi olarak tanımlanır. Reklam değeri, en iyi şekilde, reklamın tüketiciye göre değerinin genel ifadesi olarak değerlendirilebilir. Reklam, bilgilendirici eğlence değeri formunda tüketiciler için değerli olabilir; bilgilendirici eğlence değeri, sebep olunan rahatsızlık düzeyiyle birlikte, reklam değerinin tüm iskeletini oluşturur (Ducoffe, 1995).

İnternet reklamcılığı, internet hizmetlerinin özel bir çeşidi olarak görülebilir. Benzer şekilde, reklam değeri de reklamın değerinin genel ifadesi ve değerlendirmesi olarak ele alınabilir. Önceki çalışmalar, internet reklamının değerinin üç faktörle (bilgilendiricilik, eğlence ve rahatsızlık) ilgili olduğunu ve bu üç faktörün internet 
reklamcılığına yönelik tutumu etkilediğini ortaya koymuştur (Zha vd., 2015). Brackett ve Carr (2001), siber reklamcılık (cyberspace advertising) üzerine yaptıkları çalışmada, bilgi, eğlence, rahatsızlık ve güvenilirliğin reklam değerini önemli ölçüde etkilediğini ve bunun sonucunda reklamlara yönelik tutumları da etkilediğini rapor etmiştir. Reklamla etkileşime geçen tüketiciler bağlamında, tüketicilerin mevcut bilgi ihtiyaçları açısından reklamın önemi veya uygunluğu, bir tüketicinin ne kadar ilgili olduğunu belirleyebilmekte, bunun sonucunda da o reklamın değeriyle ilgili algısını etkileyebilmektedir (Wang vd., 2002, s. 1146).

Logan ve arkadaşları (2012) televizyon ile Facebook mecralarında reklam değerini karşılaştırmışlar ve her iki mecrada da eğlendiricilik ve bilgilendiriciler reklam değeri üzerinde bir etkisi olduğunu bulurken rahatsız ediciliğin bir etkisi olmadığını bulmuşlardır.

Ducoffe yaptığı çalışmasında (1995), reklamı değerli yapan şeyi anlamak amacıyla, tüketicilerin reklamdan çıkardığı temel yarar ve zararları tanımlamış ve bu varsayımsal ilişkileri ampirik olarak test etmiştir (Ducoffe, 1996):

Bilgilendiricilik: Mümkün olan en yüksek memnuniyetle sonuçlanan satın alımların gerçekleşebilmesi için reklamın tüketicileri ürün alternatifleri konusunda bilgilendirme becerisine sahip olması gerektiğine ilişkin tüketici perspektifinden bakan bir görüş birliği vardır. Tüketicilerin, markayla ilgili bilgiden bağımsız olarak, reklam deneyimini nasıl değerlendirdiği, bir diğer reklam değeri esasını oluşturur. Pazarlama teorisyenleri, reklamın birincil işlevinin, müşterilerin muhtemel en iyi satın alma kararlarını vermelerine yardımcı olmak amacıyla ürün ve hizmetlerle ilgili bilgi aktarmak olduğu konusunda genel olarak hemfikirdir. Eğer bir reklam yararlı, yerinde ve konuyla ilgili bilgi verirse, tüketiciler büyük olasılıkla o reklamı değerli olarak algılayacaktır (Murillo vd., 2016). Bilgi içeriği, reklam etkinliğinin önemli bir belirleyicisidir. Şirketler, ürün, hizmet veya markayla ilgili tüketicilere bilgi sağlamak amacıyla reklam verirler (Saxena ve Khanna, 2013). Reklam değeri, reklamın bilgilendiricilik ve eğlence değeriyle olumlu bir ilişki içindedir. Hem bilgi hem de eğlence değeri, reklamverenler ile tüketiciler arasındaki iletişim alışverişleri için önemlidir (Ducoffe, 1995).

Rahatsızlık: Reklam sinir bozan, rencide eden, aşağılayan ya da aşırı ölçüde manipülatif tekniklerden yararlandığı zaman, tüketicilerin o reklamı istenmeyen ve rahatsız edici bir etki olarak algılama intimali yüksektir. "Reklamlardan duyulan rahatsızlık, reklamı seyrederken herhangi bir nedenden dolayı rahatsızlık hissettiğimiz zaman doğar. Bu neden, kişisel veya toplumsal olabilir. Kişisel bir neden, internette belli bir göreve odaklanmışken dikkat dağıtıcı bir şey olabilir" (Saxena ve Khanna, 2013, s. 18). Literatüre göre rahatsızlık, hangi medya olursa olsun, reklamın etkinliği üzerinde negatif bir etkiye sahiptir.

Bir reklam izleyiciye çıkarcı ya da estetik değer (veya her ikisini birden) sunduğu zaman, o reklam rahatsız edici olarak algılanabilir. Reklam bir değer sunmadığı ölçüde, zorlayıcı ve nahoş (hoşa gitmeyen) olarak algılanabilir. Reklamlara yönelik 
negatif tepkiler doğurabilecek olan da işte bu rahatsızlık hissidir (Ying vd., 2009).

Eğlence: Günümüzde reklam üzerine yapılmış araştırmaların önemli bir bölümü, hoşa giden veya çekici reklamın marka tutumları üzerinde pozitif bir etkiye sahip olduğunu düşünen çelişkili düşünce üzerine kurulmuştur (Mitchell ve Olson, 1981; Shimp, 1981 'den aktaran Ducoffe, 1996, s. 23). Benzer bir anlayışla, kullanımlar ve doyumlar araştırması (uses and gratifications research), reklamın eğlence değerinin, kitlenin hayal kurma, oyalanma, estetik zevk veya duygu boşaltımı intiyaçlarını karşılayabilme becerisinde yattığını göstermiştir (McQuail, 1983’ten aktaran Ducoffe, 1996, s. 23). Reklam, tüm medya içeriğinin önemli bir bölümünü temsil eder. Bu yüzden, tüketiciler bir reklamı eğlenceli bulduğu zaman, o reklamla ilgili pozitif bir değerlendirmeye varabilirler (Ducoffe, 1995). Medya eğlence değeri sürekli olarak kabul gördüğü için ve reklam da medya içeriğinin önemli bir parçası olduğu için, reklamın eğlendirme becerisi, tüketiciler için reklam alışverişleri deneyimini artırabilir (Alwitt ve Prabhaker, 1992 'den aktaran Ducoffe, 1996, s. 24). Bilgiyle dolu, ancak eğlence içeriğinden yoksun bir reklam değersizdir (Saxena ve Khanna, 2013). Reklamı eğlenceli bulan tüketiciler, o reklamı aynı zamanda bilgilendirici olarak da değerlendirir (Ducoffe, 1995). Bu, reklamlar için eğlence ve bilginin birbirleriyle ilişkili kavramlar olduğunu göstermektedir.

Aldatıcılık: Aldatıcılık reklam endüstrisinde önemle üzerinde durulan bir konudur ve kanunlar ile düzenlenmiştir. 6502 sayılı Tüketicinin Korunması Hakkında Kanun'un 61. Maddesi uyarınca "tüketiciyi aldatıcı veya onun tecrübe ve bilgi noksanlıklarını istismar edici, can ve mal güvenliğini tehlikeye düşürücü, şiddet hareketlerini ve suç işlemeyi özendirici, kamu sağlığını bozucu, hastaları, yaşılıarı, çocukları ve engellileri istismar edici ticari reklam yapılamaz". Bu ilkelere aykırıık halinde Reklam Kurulu reklamveren, reklam ajansı ve mecra sahibine idari para cezası verebilir.

Eğer reklam argümanı örtük ya da belirsiz ise, tüketicinin argümanı anlaması zorlaşacak ve bu durum reklamın güvenilir algılanmasını düşürecektir. Yani tüketiciler güvenilir algıladıkları reklamlara daha çok değer verecekler, aldatıcılık reklam değeri üzerinde negatif bir etkiye sahip olacaktır (Ducoffe, 1995).

\section{Yöntem}

Açıklayıcı bir araştırma olan bu çalışma geleneksel ve sosyal medyadaki reklamlara yönelik tüketici tutumu ile algılanan reklam değeri arasındaki ilişkiyi açıklamaya çalışmaktadır. Amaca yönelik olarak aşağıdaki araştırma sorularına yanıt aranmıştır:

a. İncelenen mecralarda reklama yönelik tüketici tutumu ve algılanan reklam değeri nedir?

b. Reklama yönelik tüketici tutumu ve algılanan reklam değeri incelenen mecralara göre farklılaşmakta mıdır?

c. İncelenen mecralarda reklamlara yönelik tüketici tutumu ile algılanan reklam değeri arasında bir ilişki var mıdır? 
Çalışma, geleneksel mecrada televizyon; sosyal medyadan Facebook ve Instagram ile sınırlı tutulmuştur. İncelenen mecralarda reklama yönelik tutumu ve algılanan reklam değerini ölçmek için Ducoffe (1995) tarafından geliştirilen ölçek uyarlanmıştır. Ölçekte reklama yönelik tutum; bilgilendiricilik, aldatıcılık, eğlence ve rahatsız edicilik olmak üzere dört alt faktörde ölçülmektedir. Reklama yönelik tutum değişkeninin her bir alt faktörü beşli Likert ölçeğinde (1-Kesinlikle katılmıyorum, 5-kesinlikle katılıyorum) üçer ifade ile ölçülmüştür. Algılanan reklam değeri değişkeni de beşli Likert ölçeğinde (1-Kesinlikle katılmıyorum, 5-kesinlikle katılıyorum) üç ifade ile ölçülmüştür. Her üç mecra için reklama yönelik tutum ve algılanan reklam değeri ayrı ayrı ölçülmüştür. Ölçme aracının güvenilirlik katsayıları Tablo 1'de görülmektedir.

Tablo 1. Ölçme Aracının Güvenilirlik Katsayıları

\begin{tabular}{|c|c|c|c|}
\hline & TV & Facebook & Instagram \\
\hline Reklam Değeri & 0,89 & 0,93 & 0,92 \\
\hline Bilgilendiricilik & 0,75 & 0,85 & 0,83 \\
\hline Aldatıcılık & 0,76 & 0,78 & 0,81 \\
\hline Eğlendiricilik & 0,86 & 0,89 & 0,91 \\
\hline Rahatsız edicilik & 0,69 & 0,76 & 0,73 \\
\hline
\end{tabular}

Soru formu Eskişehir ilinde, nüfusun yoğun olduğu bölgelerde, kolayda örnekleme yöntemli ile seçilen 480 kişiye uygulanmış, analize uygun olmayan 20 anket çıkarıldıktan sonra 460 kişi üzerinden analizler yapılmıştır.

\section{Bulgular}

Katılımcıların yaş ortalaması 29,6'dır (ss:10,3 minimum:18, maksimum: 84). Diğer demografik değişkenlere ilişkin tanımlayıcı bilgiler Tablo 2'de görülmektedir.

Tablo 2. Tanımlayıcı İstatistikler

\begin{tabular}{|llcc|}
\hline \hline & & $\mathrm{N}$ & $\%$ \\
Cinsiyet & Kadın & 237 & 51,5 \\
\hline & Erkek & 223 & 48,5 \\
& illköğretim & 28 & 6,1 \\
& Lise & 92 & 20,0 \\
Eğitim Durumu & Yüksekokul- & 248 & 53,9 \\
& Fakülte & & \\
\hline \multirow{2}{*}{ TV seyreden } & Lisansüstü & 92 & 20,0 \\
& & 299 & 65,0
\end{tabular}


Facebook kullanan
Instagram kullanan

Ölçülen değişkenlere ait ifadelerin ortalama ve standart sapma değerleri Tablo 3'de görülmektedir.

Tablo 3. Değişkenlerin Ortalama ve Standart Sapma Değerleri

\begin{tabular}{|c|c|c|c|c|c|c|}
\hline & $\mathrm{T}$ & & Facel & & Instag & \\
\hline & Ortalama & SS & Ortalama & SS & Ortalama & SS \\
\hline Reklam Değeri & 2,59 & 1,07 & 3,05 & 1,16 & 2,86 & 1,12 \\
\hline ...... reklamları değerlidir. & 2,58 & 1,18 & 3,08 & 1,23 & 2,85 & 1,18 \\
\hline ...... reklamları faydalıdır. & 2,65 & 1,10 & 3,07 & 1,17 & 2,87 & 1,20 \\
\hline ...... reklamları önemlidir & 2,60 & 1,10 & 3,06 & 1,19 & 2,90 & 1,19 \\
\hline Bilgilendiricilik & 2,73 & 0,89 & 2,97 & 1,01 & 2,84 & 1,06 \\
\hline $\begin{array}{l}\text {....... reklamları ilgili ürün } \\
\text { bilgisini sağlar. }\end{array}$ & 2,56 & 1,03 & 2,91 & 1,11 & 2,79 & 1,17 \\
\hline $\begin{array}{l}\text {...... reklamları ürünler } \\
\text { hakkında zamanında bilgi } \\
\text { verir. }\end{array}$ & 2,85 & 1,07 & 2,97 & 1,07 & 2,90 & 1,09 \\
\hline $\begin{array}{l}\text {...... reklamları insanlara } \\
\text { intiyaç duyduklarında ürün } \\
\text { hakkında bilgi verir }\end{array}$ & 2,90 & 1,10 & 3,05 & 1,15 & 2,93 & 1,21 \\
\hline Aldatıcılık & 2,79 & 0,95 & 2,74 & 0,93 & 2,90 & 1,00 \\
\hline ....... reklamları aldatıcıdır. & 2,75 & 1,14 & 2,70 & 1,08 & 2,90 & 1,14 \\
\hline $\begin{array}{l}\text {....... reklamları yalan } \\
\text { söyler. }\end{array}$ & 2,90 & 1,14 & 2,81 & 1,05 & 2,90 & 1,10 \\
\hline $\begin{array}{l}\text { Ürünlerle ilgili önemli } \\
\text { bilgiler ......... reklamlarında } \\
\text { yer almaz }\end{array}$ & 2,86 & 1,11 & 2,79 & 1,13 & 2,92 & 1,19 \\
\hline Eğlendiricilik & 2,93 & 0,96 & 3,15 & 1,05 & 3,00 & 1,09 \\
\hline $\begin{array}{l}\text {...... reklamları } \\
\text { eğlendiricidir. }\end{array}$ & 2,89 & 1,04 & 3,18 & 1,12 & 3,00 & 1,19 \\
\hline ..... reklamları keyiflidir. & 2,95 & 1,14 & 3,05 & 1,18 & 3,01 & 1,21 \\
\hline $\begin{array}{l}\text {...... reklamları memnuniyet } \\
\text { vericidir. }\end{array}$ & 2,99 & 1,13 & 3,13 & 1,16 & 2,99 & 1,18 \\
\hline Rahatsız edicilik & 2,56 & 0,98 & 2,60 & 1,12 & 2,65 & 1,09 \\
\hline
\end{tabular}




\begin{tabular}{|l|c|c|c|c|c|c|}
\hline $\begin{array}{l}\text {..... reklamları rahatsız } \\
\text { edicidir. }\end{array}$ & 3,02 & 1,06 & 2,83 & 1,24 & 2,91 & 1,24 \\
\hline $\begin{array}{l}\text {..... reklamları insanların } \\
\text { zekasıyla alay eder. }\end{array}$ & 3,05 & 1,13 & 2,99 & 1,18 & 3,13 & 1,20 \\
\hline$\ldots . .$. çok fazla reklam vardır & 2,11 & 1,30 & 2,38 & 1,35 & 2,40 & 1,34 \\
\hline
\end{tabular}

Tutum faktörleri ile algılanan reklam değeri ortalama değerlerinin mecralara göre farklılaşıp farklılaşmadığını görmek için tek yönlü ANOVA testi uygulanmış ve Tablo 4'de görülen test sonuçlarına göre reklam değeri, bilgilendiricilik ve eğlendiricilik değişkenlerinin ortalama değerleri mecralara göre farklılaşmaktadır.

Ortalama değeri arasında fark bulunan değişkenlerde farkın hangi gruplar arasında olduğunu görmek için Scheffe testi uygulanmıştır. Test sonuçlarına göre reklam değeri değişkeni için televizyon ile Facebook (Ortalama farkı=-0,46; $p<0,05$ ) ve Instagram (Ortalama farkı=-0,27; $p<0,05$ ) arasında anlamlı bir fark bulunmuştur. Facebook ve Instagram'ın televizyona göre algılanan reklam değeri daha yüksektir.

Bilgilendiricilik değişkeni için televizyon ile Facebook (ortalama farkı=-0,24; $p<0,05$ ) arasında anlamlı bir fark bulunmuştur. Buna göre Facebook reklamları televizyon reklamlarından daha bilgilendirici algılanmaktadır.

Eğlendiricilik değişkeni için televizyon ile Facebook (ortalama farkı=-0,21; $\mathrm{p}<0,05$ ) arasında anlamlı bir fark bulunmuştur. Buna göre Facebook reklamları televizyon reklamlarından daha eğlendirici algılanmaktadır.

Tablo 4. ANOVA Testi Sonuçları

\begin{tabular}{|c|c|c|c|c|c|c|c|}
\hline \multirow{3}{*}{ Reklam Değeri } & Televizyon & $\begin{array}{c}\mathrm{N} \\
299\end{array}$ & $\begin{array}{c}\text { Ortalama } \\
2,59\end{array}$ & $\begin{array}{c}\text { Ss } \\
1,07\end{array}$ & sd & \multirow{3}{*}{13,823} & \multirow{3}{*}{$0,00^{*}$} \\
\hline & Facebook & 350 & 3,05 & 1,16 & \multirow[t]{2}{*}{2} & & \\
\hline & Instagram & 337 & 2,86 & 1,12 & & & \\
\hline \multirow{3}{*}{ Bilgilendiricilik } & Televizyon & 299 & 2,73 & 0,89 & \multirow{3}{*}{2} & \multirow{3}{*}{5,023} & \multirow{3}{*}{$0,01^{*}$} \\
\hline & Facebook & 350 & 2,97 & 1,01 & & & \\
\hline & Instagram & 337 & 2,84 & 1,06 & & & \\
\hline \multirow{3}{*}{ Aldatıcılık } & Televizyon & 299 & 2,79 & 0,95 & \multirow{3}{*}{2} & \multirow{3}{*}{2,667} & \multirow{3}{*}{0,77} \\
\hline & Facebook & 350 & 2,74 & 0,93 & & & \\
\hline & Instagram & 337 & 2,90 & 1,00 & & & \\
\hline \multirow{3}{*}{ Eğlendiricilik } & Televizyon & 299 & 2,93 & 0,96 & \multirow{3}{*}{2} & \multirow{3}{*}{3,734} & \multirow{3}{*}{$0,02^{*}$} \\
\hline & Facebook & 350 & 3,15 & 1,05 & & & \\
\hline & Instagram & 337 & 3,00 & 1,09 & & & \\
\hline
\end{tabular}




\begin{tabular}{|l|l|l|l|l|l|l|l|}
\hline \multirow{3}{*}{ Rahatsız edicilik } & Televizyon & 299 & 2,56 & 0,98 & \multirow{3}{*}{2} & \multirow{2}{*}{0,606} & \multirow{2}{*}{0,55} \\
\cline { 2 - 5 } & Facebook & 350 & 2,60 & 1,12 & \multirow{2}{*}{2} & \\
\cline { 2 - 5 } & Instagram & 337 & 2,65 & 1,09 & & & \\
\hline
\end{tabular}

${ }^{*} \mathrm{p}<0,05$

Reklama yönelik tutum değişkenlerinin, reklam değeri üzerindeki etkisi tespit etmek üzere geleneksel mecra (1) (televizyon ) ve sosyal medya (2) (Facebook ve Instagram) için iki ayrı Regresyon analizi yapılmıştır.

Geleneksel mecra için yapılan Regresyon analizinde ilk olarak değişkenler arasında çoklu bağlantı problemi kontrol edilmiştir. Değişkenler arasındaki korelasyon katsayılarının 0,90 üzerinde olması çoklu bağlantı problemini gösterir (Tabachnick ve Fidell, 2007: 89). Çalışmada kullanılan değişkenlerin aralarındaki korelasyon katsayıları 0,90'ın altındadır (Tablo 5).

Tablo 5. Değişkenler Arası Korelasyon Katsayıları (Geleneksel Mecra)

\begin{tabular}{|l|c|c|c|c|c|}
\hline & $\begin{array}{c}\text { Reklam } \\
\text { değeri }\end{array}$ & Bilgilendiricilik & Aldatıcılık & Eğlendiricilik & $\begin{array}{c}\text { Rahatsız } \\
\text { Edicilik }\end{array}$ \\
\hline $\begin{array}{l}\text { Reklam } \\
\text { değeri }\end{array}$ & - & & & & \\
\hline Bilgilendiricilik & $0,487^{\star *}$ & - & & & \\
\hline Aldatıcııı & $-0,285^{\star *}$ & $-0,110^{*}$ & - & & \\
\hline Eğlendiricilik & $0,458^{\star *}$ & $0,355^{\star *}$ & $-0,244^{* *}$ & - & \\
\hline $\begin{array}{l}\text { Rahatsız } \\
\text { edicilik }\end{array}$ & $-0,172^{* *}$ & $-0,102^{*}$ & $0,547^{\star *}$ & $-0,330^{* *}$ & - \\
\hline
\end{tabular}

** $p<0,01$ (çift yönlü), ${ }^{\star} \mathrm{P}<0,05$

Ayrıca, çoklu bağlantı probleminin test edilmesi için Tolerans ve VIF değerleri kontrol edilmiştir. Tolerans değerinin 0,10'un altında küçük değerler alması ve VIF değerinin 10'un üstünde değerler alması çoklu bağlantı probleminin işaret eder. (Pallant, 2007: 156). Analiz sonucunda Tolerans değerleri 0,65 ile 0,87 arasında değiştiği ve VIF değerlerinin ise 1,14 ile 1,51 arasında değiştiği görülmektedir. Değerler, çoklu bağlantı problemi olmadığını göstermektedir.

Regresyon analizi sonucunda, 4 bağımsız değişkenin (bilgilendiricilik, aldatıcılık, eğlendiricilik ve rahatsız edicilik) bağımlı değişken üzerindeki varyansın \%36'sını $(\mathrm{R} 2=0,36)$ açıklamaktadır. Anova analizi sonuçlarına göre regresyon modeli anlamlıdır. $(F=41,813 ; p<0,01)$.

Tablo 6. Katsayılar Tablosu (Geleneksel Mecra)

\begin{tabular}{|l|c|c|c|c|c|}
\hline & \multicolumn{2}{|c|}{$\begin{array}{c}\text { Standardize } \\
\text { Edilmemiş }\end{array}$} & $\begin{array}{c}\text { Standardize } \\
\text { Edilmiş } \\
\text { Katsayılar }\end{array}$ & Katsayılar \\
& $\beta$ & Std. Hata & Beta & Anlamlıık & Korelasyon \\
& $\beta$ & & Sıfır Sıralı & Kısmi & Kısım \\
\hline
\end{tabular}




\begin{tabular}{|l|c|c|c|c|c|c|c|c|}
\hline (Sabit Terim) & 0,863 & 0,292 & - & 2,955 & 0,000 & - & - & - \\
\hline Bilgilendiricilik & 0,440 & 0,060 & 0,364 & 7,309 & 0,000 & 0,48 & 0,39 & 0,34 \\
\hline Aldatıcılık & $-0,240$ & 0,063 & $-0,212$ & $-3,801$ & 0,000 & $-0,28$ & $-0,21$ & $-0,17$ \\
\hline Eğlendiricilik & 0,336 & 0,059 & 0,302 & 5,734 & 0,000 & 0,45 & 0,32 & 0,26 \\
\hline $\begin{array}{l}\text { Rahatsız } \\
\text { Edicilik }\end{array}$ & 0,082 & 0,063 & 0,075 & 1,315 & 0,189 & $-0,17$ & 0,08 & 0,06 \\
\hline Bağımlı Değişken: Reklam Değeri
\end{tabular}

Tablo 6'daki t değerleri incelediğinde, modele dahil edilen değişkenlerden rahatsız edicilik değişkeninin modele bir katkısının olmadığı görülmektedir. (\%5 anlamlıık düzeyinde).

Algılanan reklam değerini etkileyen faktörler açısından en yüksek Beta katsayısına bilgilendiricilik değişkeni sahiptir. Bağımlı değişken olan reklam değeri değişkenin açıklanmasına en yüksek katkıda bulanan bağımsız değişken bilgilendiricilik değişkenidir $(0,36)$. Bilgilendiricilik değişkenini, eğlendiricilik $(0,30)$, ve aldatıcılık $(-0,21)$ takip etmektedir.

Sabit terim 0,863 'dür. Bilgilendiricilik değişkenine ait parametre değeri 0,440 'dır ( $\beta=$ 0,440 ). Bilgilendiricilik bir birim arttığında reklam değeri 0,440 birim artmaktadır. Aldatıcılık bir birim arttığında reklam değeri $0,240(\beta=-0,240)$ birim azalmaktadır. Eğlendiricilik bir birim arttığında reklam değeri $0,059(\beta=0,059)$ birim artmaktadır.

Dijital mecra için yapılan Regresyon analizinde ilk olarak çoklu bağlantı problemi kontrol edilmiştir. Değişkenler arasındaki korelasyon katsayılarının 0,90 üzerinde olması çoklu bağlantı problemini gösterir (Tabachnick ve Fidell, 2007: 89). Çalışmada kullanılan değişkenlerin aralarındaki korelasyon katsayıları 0,90'ın altındadır (Tablo 7).

Tablo 7. Değişkenler Arası Korelasyon Katsayıları (Dijital Mecra)

\begin{tabular}{|l|c|c|c|c|c|}
\hline & $\begin{array}{c}\text { Reklam } \\
\text { değeri }\end{array}$ & Bilgilendiricilik & Aldatıcılık & Eğlendiricilik & $\begin{array}{c}\text { Rahatsız } \\
\text { Edicilik }\end{array}$ \\
\hline Reklam değeri & - & & & & \\
\hline Bilgilendiricilik & $0,627^{\star *}$ & - & & & \\
\hline Aldatıcılık & $-0,336^{\star *}$ & $-0,270^{* *}$ & - & & \\
\hline Eğlendiricilik & $0,612^{* *}$ & $0,506^{* *}$ & $-0,351^{\star *}$ & - & \\
\hline $\begin{array}{l}\text { Rahatsız } \\
\text { edicilik }\end{array}$ & $-0,246^{* *}$ & $-0,146^{\star *}$ & $0,473^{\star *}$ & $-0,325^{\star *}$ & - \\
\hline
\end{tabular}

${ }^{\star \star} p<0,01$ (çift yönlü)

Ayrıca, çoklu bağlantı probleminin test edilmesi için Tolerans ve VIF değerleri kontrol edilmiştir. Tolerans değerinin 0,10 'un altında küçük değerler alması ve VIF değerinin 
10'un üstünde değerler alması çoklu bağlantı probleminin işaret eder (Pallant, 2007: 156). Analiz sonucunda Tolerans değerinin 0,66 ile 0,74 arasında değiştiği ve VIF değerlerinin ise 1,34 ile 1,50 arasında değiştiği görülmektedir. Değerler, çoklu bağlantı problemi olmadığını göstermektedir.

Regresyon analizi sonucunda, 4 bağımsız değişkenin (bilgilendiricilik, aldatıcılık, eğlendiricilik ve rahatsız edicilik) bağımlı değişken üzerindeki varyansın \%52'sini $(R 2=0,52)$ açıkladığı görülmektedir. Anova analizi sonuçlarına göre regresyon modeli anlamlıdır. $(F=183,336 ; p<0,01)$.

Tablo 8'deki t değerleri incelediğinde, modele dahil edilen değişkenlerden rahatsız edicilik modele bir katkısının olmadığı görülmektedir. (\%5 anlamlılık düzeyinde).

Tablo 8. Katsayılar Tablosu (Dijital Mecra)

\begin{tabular}{|c|c|c|c|c|c|c|c|c|}
\hline & \multicolumn{2}{|c|}{$\begin{array}{c}\text { Standardize } \\
\text { Edilmemiş } \\
\text { Katsayılar }\end{array}$} & \multirow{2}{*}{$\begin{array}{c}\text { Standardize } \\
\text { Edilmiş } \\
\text { Katsayılar } \\
\text { Beta }\end{array}$} & \multirow{2}{*}{$\mathrm{t}$} & \multirow{2}{*}{ Anlamlılık } & \multicolumn{3}{|c|}{ Korelasyon } \\
\hline & $\beta$ & Std. Hata & & & & Sıfır Sıralı & & Kısım \\
\hline (Sabit Terim) & 0,785 & 0,178 & - & 4,411 & 0,000 & - & - & - \\
\hline Bilgilendiricilik & 0,460 & 0,034 & 0,418 & 13,428 & 0,000 & 0,63 & 0,46 & 0,36 \\
\hline Aldatıcılık & $-0,098$ & 0,037 & $-0,083$ & $-2,642$ & 0,000 & $-0,34$ & $-0,10$ & $-0,07$ \\
\hline Eğlendiricilik & 0,387 & 0,035 & 0,362 & 11,185 & 0,000 & 0,61 & 0,39 & 0,30 \\
\hline $\begin{array}{l}\text { Rahatsız } \\
\text { Edicilik }\end{array}$ & 0,029 & 0,032 & 0,028 & $-0,922$ & 0,357 & $-0,25$ & 0,03 & 0,02 \\
\hline
\end{tabular}

Algılanan reklam değerini etkileyen faktörler açısından standardize edilmiş katsayılar incelendiğinde en yüksek Beta katsayısına bilgilendiricilik değişkeni sahiptir. Bağımlı değişken olan reklam değeri değişkenin açıklanmasına en yüksek katkıda bulanan bağımsız değişken bilgilendiricilik değişkenidir $(0,42)$. Bilgilendircilik değişkenini, eğlendiricilik $(0,36)$, ve aldatıcılık $(-0,08)$ takip etmektedir.

Sabit terim 0,785 'tir. Bilgilendiriciliğe ait parametre değeri 0,460 'dır $(\beta=0,460)$. Bilgilendiricilik bir birim arttığında reklam değeri 0,460 birim artmaktadır. Aldatıcılık bir birim artığında reklam değeri 0,098 $(\beta=-0,098)$ birim azalmaktadır. Eğlendiricilik bir birim arttığında reklam değeri $0,387(\beta=0,387)$ birim artmaktadır.

\section{Sonuç}

Sosyal medyada yer alan reklamlar geleneksele göre daha bilgilendirici, eğlendirici bulunmakta ve reklam değeri daha yüksek algılanmaktadır. Bu durum günümüzde reklam mecrası olarak sosyal medyanın değerini bir kez daha kanıtlamaktadır. 
Çalışmada elde edilen verilere göre reklam değerine en kuvvetli katkıda bulunan bağımsız değişken bilgilendiriciliktir. Reklamda aldatıcılık arttığında reklam değeri azalmakta, eğlendiricilik arttığında reklam değeri de artmaktadır. Önceki yapıımış çalışmalardaki gibi internet ve sosyal medyanın daha doğru, gerçekçi ve interaktif reklam kaynağı olduğuna ilişkin veriler elde edilmiştir.

Çalışma, Brackett ve Carr'ın (2001), reklam değeri ile doğrudan ilişki içinde olan dört öncül tespit ettiği (bilgi vericilik, eğlence, rahatsız edicilik, güvenilirlik) çalışması ile paralellik göstermektedir. Bu çalışmada bilgilendiricilik ve eğlendiricilik reklam değerini etkileyen önemli değişkenlerdir. Farklı olarak rahatsız edicilik bu çalışmada etkili bir değişken olarak bulunamamıştır. Rahatsız edicilik değişkeninin reklam değerine bir etkisinin bulunamaması Logan ve arkadaşlarının (2012) çalışması ile paralellik göstermektedir.

Reklama yönelik tutum çalışmalarında (Tsang vd., 2004; Okozaki, 2004; Zha vd., 2015) rahatsız ediciliğin reklama yönelik tutumda bir etkisi olduğu bulunmuştur. Bu çalışmanın sonuçlarına göre reklam değeri açısından rahatsız edicilik bir etki göstermemekte, aldatıcılık, reklam değerini etkileyen bir değişken olarak ortaya çıkmaktadır. Bu açıdan reklamverenler aldatıcı reklam konusunda daha dikkatli olmak durumundadırlar.

Hem geleneksel mecrada hem sosyal medyada, ele alınan bağımsız değişkenler algılanan reklam değerinin çok az bir kısmını açıklamaktadır. Bu açıdan bakıldığında, algılanan reklam değeri üzerinde etkisi olabilecek, reklamverene yönelik tutum, marka tutumu gibi değişkenlerin de incelenmesi gerekmektedir.

\section{Kaynakça}

Aslan, A. (2017). Sosyal ağlar ve online (çevrimiçi) reklam üzerine bir değerlendirme. 1. Uluslararası İletişimde Yeni Yönelimler Konferansı'nda sözlü bildiri, İstanbul Ticaret Üniversitesi, 4-5 Mayıs, s. 230-235.

Baltar, F. ve Brunet, I. (2011), Social research 2.0: Virtual snowball sampling method using Facebook. Internet Research, 22(1), 57-74.

Becan, C. (2013). Geleneksel mecra ve internet ortamı arasındaki reklam içeriklerine yönelik algı farklııkları üzerine bir araştırma: İstanbul ili örneği. KTÜ Sosyal Bilimler Dergisi, 5, 23-41.

Boyd, D. M. ve Ellison, N. B. (2008). Social network sites: Definition, history, and scholarship. Journal of Computer-Mediated Communication, 13, 210-230.

Brackett, L. K., ve Carr, B. N. (2001). Cyberspace advertising vs. other media: Consumer vs. mature student attitudes. Journal of Advertising Research, 41(5), 23-32.

Cömert, G. ve Yükselen, C. (2017). İnternet reklamlarına yönelik tüketici inanç ve tutumlarının reklam izleme davranışları üzerine etkisi. Beykent Üniversitesi Sosyal Bilimler Dergisi, 10(1), 5161.

Curran, K., Graham, S. ve Temple, C. (2011). Advertising on Facebook. International Journal of E-Business Development (IJED), 1(1), 26-33. 
Çakır, V. ve Çakır, V. (2007). Televizyon reklamlarının algılanan değeri ve reklam tutumu ilişkisi: Bir yapısal eşitlik modeli. İstanbul Üniversitesi İletişim Fakültesi Hakemli Dergisi, 30, 37- 58.

Dar, N. A., Ahmed, M. A., Muzaffar, A. H., Nawaz, K. ve Zahid, Z. (2014). Facebook verses television: advertising value perception among students. International Journal of Business and Management Invention, 3(9), 61-70.

Ducoffe, R. E. (1995). How consumer assess the value of advertising. Journal of Current Issues and Research in Advertising, 17(1), 1-14.

Ducoffe, R. E. (1996). Advertising value and advertising on the web. Journal of Advertising Research, September/October, 21-35.

Duffett, R. G. (2017). Influence of Facebook commercial communications on generation Z's attitudes in South Africa, EJISDC, 81(8), 1-22.

Elden, M. (2013). Reklam ve reklamcılık (2. Baskı). İstanbul: Say Yayınları.

Ertugan, A. (2017). Using statistical reasoning techniques to describe the relationship between Facebook advertising effectiveness and benefits gainedi. Procedia Computer Science, 120, 132139.

İspir, N. B. ve Suher, H. K. (2009). SMS reklamlarına yönelik tüketici tutumları. Selçuk Üniversitesi Iletişim Fakültesi Akademik Dergisi, 5(4), 5-17.

Kaplan, A. M. ve Haenlein, M. (2010). Users of the world, unite! The challenges and opportunities of Social Media. Business Horizons, 53, 59-68.

Kim, J. S. (2008). A framework for advertising in the digital age. Journal of Advertising Research, September, 310-312.

Lee, D., Kim, H. S. ve Kim, J. K. (2011). The impact of online brand community type on consumer's community engagement behaviors: Consumer-created vs. marketer-created online brand community in online social-networking web sites. Cyberpsychology, Behavior, And Social Networking, 14(1-2).

Logan, K., Bright, L. F. ve Gangadharbatla, H. (2012). Facebook versus television: Advertising value perceptions among females. Journal of Research in Interactive Marketing, 6(3), 164-179.

MacKenzie, S. B.; Lutz, R. J. ve Belch, G. E. (1986). The role of attitude toward the ad as a mediator of advertising effectiveness: A test of competing explanations. Journal of Marketing Research, 23(2), 130-43.

Mangold, G. W. ve Faulds, D. J. (2009). Social media: The new hybrid element of the promotion mix. Business Horizons, 52, 357-365.

Mehta, A. (2000). Advertising attitudes and advertising effectiveness. Journal of Advertising Research, 40(3), 67- 72.

Murillo, E., Merino, M. ve Núñez, A. (2016). The advertising value of Twitter Ads: A study among Mexican Millennials. Review of Business Management, 18(61), Jul./Sept., 436-456.

Odabaşı, Y. ve Barış, G. (2013). Tüketici Davranışı (13. Baskı). İstanbul: MediaCat. 
Okazaki, S. (2004). How Do Japanese consumers perceive wireless ads? A multivariate analysis. International Journal of Advertising, 23(4), 429-454.

Pallant, J. (2007). SPSS survival manual (3 ${ }^{\text {rd }}$ Ed.). New York: Open University Press.

Pavlou, P. A. ve Stewart, D. W. (2000). Measuring the effects and effectiveness of interactive advertising: A research agenda. Journal of Interactive Advertising, 1(1), 62-78.

Saxena, A. ve Khanna, U. (2013). Advertising on social network sites: A structural equation modelling approach. Vision, 17(1), 17-25.

Shamdasani, P. N., Stanaland, A. J. S. ve Tan, J. (2001). Location, location, location: Insights for advertising piacement on the Web. Journal of Advertising Research, July-August, 7-21.

Süher, K. ve İspir, N. B. (2010). Televizyon ve gazetede reklamdan kaçınmayı etkileyen değişkenler. Selçuk Iletişim, 6(2), 5-23.

Tabachnick, B. G. ve Fidell, L. S. (2007). Using multivariate statistics ( $5^{\text {th }}$ Ed.). New York: Pearson. Toros, S. (2016). Reklam iletişiminde dönüşümler: çevrimiçi reklam ve tüketici. İktisat ve Toplum Dergisi, 71, 24-32, https://www.researchgate.net/profile/Secil_Toros/ publication/308694206_Reklam_lletisiminde_Donusumler_Cevrimici_Reklam_ve_Tuketiciler/ links/5811b0af08aee15d4915104c/Reklam-Iletisiminde-Doenuesuemler-Cevrimici-Reklam-veTuketiciler.pdf, Erişim Tarihi: 11.07.2108

Tsang, M. M., Ho, S. ve Liang T. (2004). Consumer attitudes toward mobile advertising: An empirical study. International Journal of Electronic Commerce, 8(3), 65-78.

Wang, C., Zhang, P., Choi, R. ve D'Eredita, M. (2002). Understanding consumers attitude toward advertising. Eighth Americas Conference on Information Systems AMCIS 2002 Proceedings, ss. $1142-1148$.

Ying, L., Korneliussen, T. ve Gronhaug, K. (2009). The effect of ad value, ad placement and ad execution on the perceived intrusiveness of web advertisements. International Journal of Advertising, 28(4), 623-638.

Zha, X, Li, J. ve Yan, Y. (2015). Advertising value and credibility transfer: Attitude toward Web advertising and online information acquisition. Behaviour \& Information Technology, 34(5), 520532. 